\title{
Royal jelly: a natural therapeutic?
}

\section{Arı sütü: doğal bir terapötik mi?}

\author{
Ali Korhan Sığ ${ }^{1^{*}(\mathbb{D})}$, Özlem Öz-Sığ ${ }^{2}$ (D), Mustafa Güney ${ }^{3}$ \\ ${ }^{1}$ Hacettepe University Faculty of Medicine, Department of Medical Microbiology, Ankara, Turkey \\ ${ }^{2}$ Balikesir Ataturk City Hospital, Department of Pediatrics, Balikesir, Turkey \\ ${ }^{3}$ University of Health Sciences, Gulhane Faculty of Medicine, Department of Medical Microbiology, Ankara, Turkey \\ * Corresponding author: Ali Korhan Sig E-mail: dr_korhan@hotmail.com ORCID: 0000-0003-2907-257X \\ Received: 21 December 2018 Accepted: 17 February 2019
}

\begin{abstract}
Royal jelly is a secretion of honeybees that is actually for feeding of bee larvae. It contains many bioactive substances such as jelleins, royalisin, major royal jelly proteins and 10-hydroxy-2-decenoic acid. Recently, many studies were published investigating activities of royal jelly. In overall, royal jelly found to have antioxidant, neurotrophic, antidiabetic, hypocholesterolemic, regulatory on blood pressure, antimicrobial, immunomodulatory, anti-tumor and tissue-protective effects. These activities are strongly related to each other and cannot be evaluated separately. Researchers claim that royal jelly can be an excellent therapeutic agent (or an additional agent), especially in treatments of cancer and metabolic syndrome. However, there are huge gaps due to limited number of in vivo studies and there are standardization issues both for usage and investigations. Furthermore, wide variability of contents in royal jelly due to geographic locations, climate, etc also causes a problem in choice of exact royal jelly. Currently it seems to be safe and effective nutritious agent for healthy people, but it is hard to gain an overall perspective in usage as a therapeutic, since there is a necessity of wider studies with more different types of royal jelly.
\end{abstract}

Keywords: royal jelly, apitherapy, honeybee products, biopharmaceuticals, complementary medicine, integrative medicine 


\section{öz}

Arı sütü aslen arı larvalarının beslenmesi için bal arıları tarafından üretilen bir sekresyondur. Jelleinler, royalizin, ana arı sütü proteinleri ve 10-hidroksi-2-desenoik asit gibi çok sayıda biyoaktif madde içermektedir. Son yıllarda arı sütü konusunda çok sayıda makale yayımlanmıştır. Genel olarak, arı sütü, antioksidan, nörotropik, antidiyabetik, hipokolesterolemik, kan basıncı düzenleyici, antimikrobiyal, immünomodülatör, anti-tümör ve doku koruyucu etkileri göstermektedir. Bu etkiler aslen bir bütündür ve mekanizmaları ayrı ayrı değerlendirmek mümkün değildir. Araştırmacılar, özellikle kanser ve metabolik sendrom tedavisinde iyi bir tedavi ajanı (veya tedaviye ek bir ajan) olabileceğini iddia etmektedir. Öte yandan, in vivo çalışmaların sayısı son derece sınırlıdır ve hem araştırma hem kullanım alanlarında standardizasyon sorunu vardır. Ayrıca, coğrafi konum, iklim gibi koşullara bağlı olarak arı sütü içeriğinin ciddi farklılıklar göstermesi, arı sütünün seçiminde sorunlar yaratmaktadır. Şu an için, sağlıklı insanlarda güvenli ve etkin bir besleyici gıda olarak gözükmekte, fakat terapötik kullanımı konusunda genel bir görüş elde etmek mümkün gözükmemektedir. Farklı türlerde arı sütleri üzerinde daha geniş çaplı araştırmalar yapılmalıdır.

Anahtar kelimeler: arı sütü, apiterapi, arı ürünleri, biyofarmasötik ajanlar, geleneksel ve tamamlayıcı tıp

\section{INTRODUCTION}

Royal jelly (RJ) is a secretion of honeybees that is actually for feeding of bee larvae. Although there are many ancient medical records of its usage, it has been widely used and consumed especially in Asia. Recently, it has been reported that RJ has various actions with the potential of improving human health, especially focusing on reproductive health, neurologic diseases, wound healing, anti-aging and anticancer via several mechanisms [1,2]. Antioxidant, neurotrophic, hypocholesterolemic, tissue-protective, regulatory on blood pressure, antimicrobial, antiinflammatory, immunomodulatory and antitumor effects were observed in many scientific studies. These actions mainly depend on bioactive substances such as jelleins, royalisin, major royal jelly proteins (MRJPs) and 10hydroxy-2-decenoic acid (10-HDA). These substances have strong pharmaceutical actions on human physiology [3-5].

\section{POTENTIAL ACTIONS}

It is very difficult to line strong borders in order to separate modes of actions from each other. However, studies on RJ have mainly focused singularly on particular actions or some of particular substances. Despite of these issues, it is possible to make a general vision and explain potential actions in separated headings. In overall, RJ has antioxidant, neurotrophic, antidiabetic, hypocholesterolemic, regulatory on blood pressure, antimicrobial, immunomodulatory, antitumor and tissue-protective effects.

\section{Antioxidant Activity and Tissue-protective Effect}

Although the effect seems to be time-dependent, activity against oxidative stress and DNA damage was shown in studies on rats [4,6]. Narita et al. [7] studied on endocrinologic alterations on mice and reported that $\mathrm{RJ}$ had a strong regulatory effect against aging. Another study stated that radiation induced apopytosis can significantly be prevented with RJ [8]. El-Nekeety et al. [9] reported strong histopathologically antioxidative activity on the livers and kidneys of RJ-consuming mice during experimental oxidative damage by fumonisin. Similar effects of RJ against cisplatin-induced toxicity were studied by Silici et al. [10], and they reported significant improvements on testosterone levels, normal sperm ratios and on histopathologic damage of testicle, prostate and epididymis tissues in RJ group. Anbara et al. [11] and Manas et al. [12] were also stated endocrinologic regulation and decrease on testicular damage with RJ. Another study on female rats indicated that RJ had the potential of being therapeutic agent regarding female infertility via same antioxidant activities [13]. Abdel-Hafez et al. [14] investigated cyclophosphamide-induced prostate damage, and observed that RJ significantly reduced eNOS and Bax expression, regulated biochemical markers and decreased histopathological damage. Pajovic et al. [15] also reported similar effects of RJ as a potential therapeutic agent in benign prostatic hyperplasia.

In many studies, RJ also found protective via antioxidant mechanisms in other body parts. Studies with cisplatin and oxymetholone strongly indicated hepatoprotective and nephroprotective effects [16-20]. Malekinejad et al. [21] also reported cardioprotective activity dose dependently. In a recent study, researchers found particular improvements on diabetic markers and liver function panel results by regular consuming of RJ in streptozotocin-induced diabetic rats. Regarding these findings, they claimed a direct relationship with antioxidant activity of RJ [22]. Similarly, Kanbur et al. 
[23] studied on paracetamol-induced hepatotoxicity, and they stated that they could not find any difference between RJ and control group, with significant hepatotoxicity in single-parasetamol group. Additionally, Kamakura et al. [24] published an in vitro study indicating that RJ proteins can stimulate proliferation of rat hepatocytes. Interestingly, oral consuming of RJ was also found to have an effect against oxidative stress in the dry eye by increasing lacrimal tear secretions [25].

A few studies focused on bone tissues. Araki et al. [26] compared mice tibia cells between RJ and control groups, and they stated that RJ had positive impact on bone formation such as increasing the extracellular matrix. The effect mechanism is actually still under shadows, but Hidaka et al. [27] reported an indirect pathway indicating that RJ actually stimulates gastrointestinal calcium absorption, but it does not affect by blocking parathyroid hormone mechanisms to prevent osteoporosis.

Although there are several studies on tissue damages, data about molecular interactions of $\mathrm{RJ}$ is very limited. There are articles indicating that RJ somehow provokes avtivities of glutathione peroxidase and superoxide dismutase [10,28]. In an example study of Makino et al. [29], it was found that RJ substances had a direct regulatory effect on expression of superoxide dismutase. In another study on central nervous system, significant positive activities of RJ on glutathione mechanisms were stated [30]. However, there are also reports, which cause suspicion about these specialties of RJ [31]. Of course, it should be noted that chemical compositions of bee products are strongly related with geographical and climate conditions, and chemical diversity is commonly observed. Regarding to this, potential effects may change from one RJ to another. Additionally, there isn't standardization on studies of bee products, so different results may be caused. Thus, in vivo studies from different locations and with different RJs have a great importance.

\section{Neurotrophic Effects}

Antioxidant activities of RJ are actually expected to have similar effects on neuron tissue, but neurotrophic effects have become also a center of focus. As an example, in the study of Hattori et al. [32] 10-HDA was found to stimulate neurogenesis and differenciation of various types of nervous system cells such as neurons, astrocytes and oligodendrocytes. In another study of Hattori et al. [33], RJ was found to be successful to regain cognitive abilities in hippocampal dentate gyrus damaged mice. In an experimental Alzheimer's disease model, RJ consumption significantly improved spatial memory in mice [34]. In the same model, RJ reduced neurodegeneration and resulted particular improving effects against amyloid-beta toxicity [35]. A recent study indicated that $\mathrm{RJ}$ consumption increased cognitive functions and improved spatial memory by effecting on sistein and taurin metabolisms in elder mice [36]. Hashimoto et al. [37] investigated RJ-induced potential alterations on mRNA expressions of neutrophic factors, their receptors and neural cell markers to observe neuroprotective effects and variations of neurogenesis. They found that mRNA expressions of glial cell line-derived neurotrophic factor (a potent neurotrophic factor), neurofilament $\mathrm{H}$ (a specific marker for neural axons in hippocampus) were increased by RJ. Morita et al. [38] compared healthy human control and RJ groups and they reported RJ group showed statistically significant superiorities about mental health, handling mental stress and social functionality. Additionally, in an interesting study, Minami et al. [39] stated that RJ consumption reduced postmenoposal neurologic symptoms in rat models. As understood, studies are mostly on animal models, and there is a very limited data, but it seems RJ provides a huge potential especially for neurodegenerative diseases.

\section{Antidiabetic, Hypocholesterolemic, Regulatory on Blood Pressure}

RJ can decrease serum glucose level by its insulin-like peptides and other contents (sulphur, Vit B3, Vit H, etc) [3]. Morita et al. [38] stated that RJ did not make any change in $\mathrm{HbA} 1 \mathrm{c}$ levels, but they observed serious improvements in insulinogenic index and fasting plasma glucose (FPG) ratios, that indicates stimulation of insulin secretion. They also claimed that RJ caused an increase in testosterone levels, which resulted with arised glucose tolerance and eritropoiesis. Despite of these data, Pourmoradian et al. [28] found decreasing $\mathrm{HbA} 1 \mathrm{c}$ levels, but for FPG ratios, there was not any alteration. This conflict may be a result of sample size or dose-dependency, since researchers also reported arised insulin levels and accordingly, decreased serum glucose. Zamami et al. [40] stimulated hypertriglyceridemia and hyperinsulinemia in rats, and in the RJ group, there was significantly lower triglyceride and insulin levels without any particular difference in serum glucose levels comparing to control group. They commented that these results indicated an effect of RJ against insulin resistance. In another study, RJ was found as a serious regulatory agent for diabetic biomarkers [22]. RJ also seems to improve fertilization skills in diabetic mice [41]. Münstedt et al. [42] studied on serum glucose levels during oral glucose tolerance tests in human volunteers and levels were found significantly lower in RJ group, which indicated RJ to have insulin-like activity. 
Yoshida et al. [43] focused on potential molecular changes caused by long-term RJ consumption. Many alterations were found such as decreasing of G6Pase expression, increasing of AdipoQ ve AdipoR1 mRNA expression. In another study, alterations were also reported in apolipoprotein levels [44].

As understood, RJ consumption does not only affect serum glucose, but also triglyceride (TG) and cholesterole levels. In the study of Guo et al. [45] on healthy human volunteers, RJ provided significant decrease in total cholesterole and LDL, despite there was no change in HDL and TG levels. Similar decreases on LDL and total cholesterol, and stable conditions of TG and HDL were also observed by Chui et al. [46]. In another study on postmenouposal volunteers, same alterations were found for total cholestrole and LDL, but significant increase in HDL levels was also noted [47]. On the other hand, arised $\mathrm{HDL}$, decreased $\mathrm{LDL}$ and unchanging TG levels were reported with RJ consumption in a study on hypercholesterolemic patients [48]. In a recent metaanalysis study, long-term consumption of RJ was pointed as the critical key for the particular decrease in total cholesterol and LDL [49]. RJ seems to have more complex activities also in adipose tissue. Yoneshiro et al. [50] stated that RJ had a regulatory effect on hepatic TG levels and provided changes in white adipose tissue in a positive way. They also observed molecular regulations in brown adipose tissue.

There are only a few studies about effects of RJ on blood pressure. Takaki-Doi et al. [51] reported that RJ contains protein fractions, which shows anti-hypertensive effect by inhibiting angiotensin-converting enzyme-1. In a recent study of Fan et al. [52], inhibitory activity of MJP-1 on vascular smooth muscle contraction and muscle cell proliferation was found.

In overall, RJ seems to have huge potential and strong utilities in fighting against so-called "novel epidemic" obesity, hypertension, diabetes mellitus and their combination named metabolic syndrome. However, molecular mechanisms have not been totally understood yet and the number of human studies is very few. So, RJ is very promising and deserves the focus of researchers to adapt it into routine treatment models.

\section{Anti-Tumor Effects}

Of course, anti-cancer activity is strongly related with antioxidant mechanisms. However, RJ has been investigated for primarily anti-tumoral actions, too. Townsend et al. [53] studied on 10-HDA against four different tumor tissues and stated that both RJ as a whole and 10-HDA itself had antitumoral activities. Shirzad et al. [54] observed that fibrosarcoma tissues in mice showed significant difference in tumor growth in favor of RJ group. They claimed that RJ provided this action by its immunomodulatory effect, and they could observe the difference in long-term therapies. They also commented that this effect may be more apperantly provided by comsumption of RJ before tumoral formation occurence. Zhang et al. [55] supported these data, since they also found inhibitory effet of RJ on tumor growth, furthermore they noted that this effect depended on especially cytokine regulation. On the other hand, the study of Izuta et al. [56] indicated notably direct mechanisms. They observed that RJ inhibited cell proliferation and cell migration, and it also corrupted tumor vascularization by inhibiting vascular endothelial growth factor. It seems RJ has anti-cancer effects especially with long-term consumption, and its immunomodulatory activity is an additional utility, but it provides also a potential for novel chemotherapeutics.

\section{Immunologic Activities}

Immunologic effects of RJ are strictly connected with antioxidant and anti-tumor effects. However, immunologic activities caused by RJ have a wider perspective. Immunomodulatory, cytokine regulatory and other actions including cell-level alterations were reported. Sver et al. [57] reported immunomodulatory effect dose-dependently. In cytokine studies, RJ was found as an inhibitor for proinflammatory cytokine release, reducer for IL-2 release, inhibitor for expression of IL-2 cytokine receptors [58,59]. Despite of these, RJ stimulated IL-10 production, which is also known as human cytokine synthesis inbitory factor and acts as an anti-inflammatory cytokine $[59,60]$. Kohno et al. [58] also reported that fatty acids of RJ downregulated splenic T cells and expression of MHC-II and CD86, and adiitionally inhibited IL-12 synthesis. Gasic et al. [61] also studied on RJ fatty acids, they showed immunomodulatory effects on T cells and significant decrease of IL-2 and nitric oxide in vitro. In a study on immunodeficient mice, $1 \% \mathrm{RJ}$ consumption resulted with significant regulation of cytokine release and T, B cell reponses [62]. An interesting recent study indicated that long-term $\mathrm{RJ}$ consumption caused strong reduction in pulmonary fibrosis and suppression in proinflammatory cytokines and IFNY [63]. These immunoregulatory activities caused a questionnaire whether RJ may be a solution to autoinflammatory diseases. Mannoor et al. [64] studied on experimental systemic lupus erythematosus (SLE) mice model comparing RJ and control groups. RJ significantly delayed emerging of symptoms, decreased proteinuria, and reduced anti-dsDNA antibody, anti-ssDNA antibody, anti-erythrocyte antibody and splenic autoreactive $B$ cells. In another study on pediatric SLE 
patients, three-month $\mathrm{RJ}$ consumption resulted with a particular increase in CD4+ regulatory $\mathrm{T}$ cell levels and decrease in apoptotic CD4+ T cell cell levels [65]. Erem et al. [66] studied $T$ cell culture for potential effects of RJ on healthy human and patients with Graves disease. RJ inclined the Th1/Th2 ratio to Th1 side, increased IFNY levels, decreased TNFa, IL-4, IL-10 and so, suppressed humoral immunity. Due to strong relations between Graves disease and thyroid-stimulating hormone receptor antibody, they claimed that suppression of humoral immunity could be a solution to this pathology. As understood, RJ has various actions, even seems to be opposite in different conditions, which means the mechanism is actually seriously complex. On the other hand, immunomodulatory effects are obvious, so RJ and its contents should be a topic of many human and animal studies.

\section{Antimicrobial Effects}

Antimicrobial effects of $\mathrm{RJ}$ have relatively less studied regarding other actions. RJ contents such as royalisin, 10DHA, MJPs and jelleins were actually investigated for antibacterial activities $[67,68]$. MRJPs and jelleins were found effective especially against bacterial cell wall and bactericidal activities were observed on common gram positive and negative pathogens [69]. In an interesting study comparing $\mathrm{RJ}$ and $2 \%$ chlorhexidine solution, RJ was reported to have serious potential for dental procedures as a disinfectant [70]. Dinkov et al. [71] stated significant inhibitory activity against methicillin-resistant Staphylocuccus aureus, which is a problem for hospitalacquired infections. Similar results were found against Aeromonas hydrophila [72]. Mierzejewski [73] performed a wider study with honey, propolis and RJ against several bacterial agents, comparing with some antibiotics. Although each bee product had antibacterial activity, potency seemed to be different according to pathogen agent and the product. Interestingly, RJ did not show any activity against Pseudomonas aeruginosa, but it reduced adhesion ability of the bacteria [74]. So, in vitro antibacterial activity of RJ may not be the same as in vivo, which needs further studies for actual evaluation. Antifungal activity of RJ is controversial and there is very limited data about this topic [75]. In overall, consideration of bee products as a whole (or combined) seems to be more appropriate according to the current data. On the other hand, antimicrobial molecules provide potential of being future therapeutics. Recently, antimicrobial activities of bee products are routinely used in especially wound care [76].

\section{CONCLUSION}

Therapeutic effects of bee products and their bioactive substances are major topics of many studies. RJ comes forward with its strong antioxidant and immunomodulatory activities, but it has the potential of having other effects. Generally, researchers are divided into two groups, claiming that these bee products cannot be evaluated as different biopharmaceuticals or investigating each product (even each substance) singularly. For now this remains unclear, both opinions seem to be true, that valuable research studies with wide future perspectives are published. However, RJ and other bee products show wide variability according to climate, ecosystem and geographic conditions. Because, generally, studies are localized, it is hard to gain an overall perspective, which results with the necessity of wider studies with more different types of RJ. Furthermore, there are only a few human studies, which were performed by focusing on only specific topics and with limited sample sizes. In addition, standardization is also a problem for researches, since extraction protocols affect study results, in vitro efficiency and potency [61].

More questions come forward in case of RJ usage as a therapeutic. There is no standard dosage recommendation to gain desired effects. Potential intoxication and side effects remain unclear. Although RJ, as in combination, provides a potential to avoid adverse effects of chemotherapeutics, comorbidities of patients and unknown effects of RJ remain as a question for these patient groups. Because it contains many immunogenic substances, allergic reactions including anaphylaxis must also be considered [77].

In conclusion, RJ provides many effects that can be beneficial as a therapeutic or a substance of a combination therapy. There are gaps worth to investigate in order to put $\mathrm{RJ}$ in routine applications, but currently it seems to be safe and effective nutritious agent. More in vitro and in vivo studies are needed for therapeutic usage, but also for better understanding its medicinal potential.

\section{DECLARATION OF CONFLICT OF INTEREST}

The Authors wish to confirm that there are no known conflicts of interest associated with this publication and there has been no significant financial support for this work that could have influenced its outcome. 


\section{REFERENCES}

1. Cherbuliez T. Apitherapy - The Use of Honeybee Products. In: Grassberger M, Sherman RA, Gileva OS, Kim $\mathrm{CMH}$, Mumcuoglu KY (editors). Biotherapy - History, Principles and Practice: A Practical Guide to the Diagnosis and Treatment of Disease using Living Organisms. London: Springer Science \& Business Media; 2013: 113-46.

2. Pasupuleti VR, Sammugam L, Ramesh N, Gan SH. Honey, propolis, and royal jelly: a comprehensive review of their biological actions and health benefits. Oxid Med Cell Longev 2017. (doi: 10.1155/2017/1259510).

3. Pavel $\mathrm{Cl}$, Mărghitaş LA, Bobiş O, Dezmirean DS, Şapcaliu A, Radoi I, Mădaş MN. Biological activities of royal jellyreview. Scientific Papers Animal Science and Biotechnologies 2011; 44: 108-18.

4. Cornara L, Biagi M, Xiao J, Burlando B. Therapeutic properties of bioactive compounds from different honeybee products. Front Pharmacol 2017. (doi: 10.3389/fphar.2017.00412).

5. Viuda-Martos M, Ruiz-Navajas $\mathrm{Y}$, Fernández-López J, Pérez-Álvarez JA. Functional properties of honey, propolis, and royal jelly. J Food Sci 2008; 73: 117-24.

6. Inoue SI, Koya-Miyata S, Ushio S, Iwaki K, Ikeda M, Kurimoto M. Royal Jelly prolongs the life span of $\mathrm{C} 3 \mathrm{H} / \mathrm{HeJ}$ mice: correlation with reduced DNA damage. Exp Gerontol 2003; 38: 965-9.

7. Narita Y, Ohta S, Suzuki KM, Nemoto T, Abe K, Mishima S. Effects of long-term administration of royal jelly on pituitary weight and gene expression in middle-aged female rats. Biosci Biotechnol Biochem 2009; 73: 431-3.

8. Rafat N, Monfared AS, Shahidi M, Pourfallah TA. The modulating effect of royal jelly consumption against radiation-induced apoptosis in human peripheral blood leukocytes. J Med Phys 2016; 41: 52-7.

9. El-Nekeety AA, El-Kholy W, Abbas NF, Ebaid A, Amra HA, Abdel-Wahhab MA. Efficacy of royal jelly against the oxidative stress of fumonisin in rats. Toxicon 2007; 50: 256-69.

10. Silici S, Ekmekcioglu O, Eraslan G, Demirtas A. Antioxidative effect of royal jelly in cisplatin-induced testes damage. Urology 2009; 74: 545-51.
11. Anbara H, Shahrooz R, Malekinejad H, Saadati S. Protective Effects of Royal Jelly and Vitamin $C$ against Experimental Hemolytic Anemia on Sex Hormones and Histochemical Testicle Tissue Histochemistry of Adult Mice. JSSU 2016; 23: 1140-54.

12. Manas GE, Najafi G. Protective effects of royal jelly on the histomorphologic, oxidative stress and sperm parameters in Ofloxacin treated rat. Comp Clin Path 2017; 26: 1111-5.

13. Ghanbari E, Khazaei MR, Khazaei M, Nejati V. Royal Jelly Promotes Ovarian Follicles Growth and Increases Steroid Hormones in Immature Rats. Int J Fertil Steril 2018; 11: 263-9.

14. Abdel-Hafez SMN, Rifaai RA, Abdelzaher WY. Possible protective effect of royal jelly against cyclophosphamide induced prostatic damage in male albino rats; a biochemical, histological and immuno-histo-chemical study. Biomed Pharmacother 2017; 90: 15-23.

15. Pajovic B, Radojevic N, Dimitrovski A, Tomovic S, Vukovic $M$. The therapeutic potential of royal jelly in benign prostatic hyperplasia. Comparison with contemporary literature. Aging Male 2016; 19: 192-6.

16. Karadeniz A, Simsek N, Karakus E, et al. Royal jelly modulates oxidative stress and apoptosis in liver and kidneys of rats treated with cisplatin. Oxid Med Cell Longev 2011. (doi: 10.1155/2011/981793).

17. Yapar K, Cavusoglu K, Oruc E, Yalcin E. Protective effect of royal jelly and green tea extracts effect against cisplatininduced nephrotoxicity in mice: a comparative study. J Med Food 2009; 12: 1136-42.

18. Osama H, Abdullah A, Gamal B, Emad D, Sayed D, Hussein E, et al. Effect of Honey and Royal Jelly against CisplatinInduced Nephrotoxicity in Patients with Cancer. J Am Coll Nutr 2017. (doi: 10.1080/07315724.2017.1292157).

19. Ibrahim A, Eldaim MAA, Abdel-Daim MM. Nephroprotective effect of bee honey and royal jelly against subchronic cisplatin toxicity in rats. Cytotechnology 2016; 68: 1039-48.

20. Nejati V, Zahmatkesh E, Babaei M. Protective Effects of Royal Jelly on Oxymetholone-Induced Liver Injury in Mice. Iran Biomed J 2016; 20: 229-34. 
21. Malekinejad $H$, Ahsan S, Delkhosh-Kasmaie F, Cheraghi $\mathrm{H}$, Rezaei-Golmisheh A, Janbaz-Acyabar $\mathrm{H}$. Cardioprotective effect of royal jelly on paclitaxelinduced cardio-toxicity in rats. Iran J Basic Med Sci 2016; 19: 221-7.

22. Ghanbari E, Nejati V, Khazaei M. Improvement in serum biochemical alterations and oxidative stress of liver and pancreas following use of royal jelly in streptozotocininduced diabetic rats. Cell Journal (Yakhteh) 2016; 18: 362.

23. Kanbur M, Eraslan G, Beyaz L, Silici S, Liman BC, Altinordulu S, Atasever A. The effects of royal jelly on liver damage induced by paracetamol in mice. Exp Toxicol Pathol 2009; 61: 123-32.

24. Kamakura M, Suenobu N, Fukushima M. Fifty-seven-kDa protein in royal jelly enhances proliferation of primary cultured rat hepatocytes and increases albumin production in the absence of serum. Biochem Biophys Res Commun 2001; 282: 865-74.

25. Inoue S, Kawashima M, Hisamura $R$, et al. Clinical evaluation of a royal jelly supplementation for the restoration of dry eye: A prospective randomized double blind placebo controlled study and an experimental mouse model. PloS One 2017. (doi: 10.1371/journal.pone.0169069).

26. Narita Y, Nomura J, Ohta S, et al. Royal jelly stimulates bone formation: physiologic and nutrigenomic studies with mice and cell lines. Biosci Biotechnol Biochem 2006; 70: 2508-14.

27. Hidaka S, Okamoto Y, Uchiyama S, et al. Royal jelly prevents osteoporosis in rats: beneficial effects in ovariectomy model and in bone tissue culture model. Evid Based Complement Alternat Med 2006. (doi: 10.1093/ecam/nel019).

28. Pourmoradian S, Mahdavi R, Mobasseri M, Faramarzi E, Mobasseri $M$. Effects of royal jelly supplementation on glycemic control and oxidative stress factors in type 2 diabetic female: A randomized clinical trial. Chin J Integr Med 2014; 20(5): 347-352.

29. Makino J, Ogasawara R, Kamiya T, et al. Royal Jelly constituents increase the expression of extracellular superoxide dismutase through histone acetylation in monocytic THP-1 cells. J Nat Prod 2016; 79: 1137-43.
30. Teixeira RR, de Souza AV, Peixoto LG, et al. Royal jelly decreases corticosterone levels and improves the brain antioxidant system in restraint and cold stressed rats. Neurosci Lett 2017; 655: 179-85.

31. Juszczak L, Gałkowska D, Ostrowska M, Socha R. Antioxidant activity of honey supplemented with bee products. Nat Prod Res 2016; 30: 1436-9.

32. Hattori N, Nomoto H, Fukumitsu H, Mishima S, Furukawa S. Royal jelly and its unique fatty acid, 10-hydroxy-trans2-decenoic acid, promote neurogenesis by neural stem/progenitor cells in vitro. Biomed Res 2007; 28: 2616.

33. Hattori N, Ohta S, Sakamoto T, Mishima S, Furukawa S. Royal jelly facilitates restoration of the cognitive ability in trimethyltin-intoxicated mice. Evid Based Complement Alternat Med 2011. (doi: 10.1093/ecam/nep029).

34. Zamani Z, Reisi P, Alaei H, Pilehvarian AA. Effect of Royal Jelly on spatial learning and memory in rat model of streptozotocin-induced sporadic Alzheimer's disease. Adv Biomed Res 2012. (doi: 10.4103/2277-9175.98150).

35. Wang X, Cao M, Dong Y. Royal jelly promotes DAF-16mediated proteostasis to tolerate $\beta$-amyloid toxicity in C.elegans model of Alzheimer's disease. Oncotarget 2016; 7: 54183-93.

36. Chen D, Liu F, Wan JB, Lai CQ, Shen LR. Effect of Major Royal Jelly Proteins on Spatial Memory in Aged Rats: Metabolomics Analysis in Urine. J Agric Food Chem 2017; 65: 3151-9.

37. Hashimoto $M$, Kanda $M$, Ikeno $K$, et al. Oral administration of royal jelly facilitates mRNA expression of glial cell linederived neurotrophic factor and neurofilament $\mathrm{H}$ in the hippocampus of the adult mouse brain. Biosci Biotechnol Biochem 2005; 69: 800-5.

38. Morita H, Ikeda T, Kajita $\mathrm{K}$, et al. Effect of royal jelly ingestion for six months on healthy volunteers. Nutr J 2012; 11: 77.

39. Minami A, Matsushita $H$, leno $D$, Matsuda $Y$, Horii $Y$, Ishii $A$, et al. Improvement of neurological disorders in postmenopausal model rats by administration of royal jelly. Climacteric 2016; 19: 568-73.

40. Zamami Y, Takatori S, Goda M, et al. Royal jelly ameliorates insulin resistance in fructose-drinking rats. Biol Pharm Bull 2008; 31: 2103-7. 
41. Ghanbari E, Nejati V, Khazaei M. Antioxidant and protective effects of Royal jelly on histopathological changes in testis of diabetic rats. Int J Reprod Biomed 2016; 14: 519-26.

42. Münstedt K, Bargello M, Hauenschild A. Royal jelly reduces the serum glucose levels in healthy subjects. J Med Food 2009; 12: 1170-2.

43. Yoshida M, Hayashi K, Watadani R, et al. Royal jelly improves hyperglycemia in obese/diabetic KK-Ay mice. J Vet Med Sci 2017; 79: 299-307.

44. Khoshpey B, Djazayeri S, Amiri F, et al. Effect of royal jelly intake on serum glucose, apolipoprotein AI (ApoA-I), apolipoprotein $B(A p o B)$ and $A p o B / A p o A-I$ ratios in patients with type 2 diabetes: A randomized, doubleblind clinical trial study. Can J Diabetes 2016; 40: 324-8.

45. Guo H, Saiga A, Sato M, Miyazawa I, Shibata M, Takahata Y, Morimatsu F. Royal jelly supplementation improves lipoprotein metabolism in humans. J Nutr Sci Vitaminol 2007; 53: 345-8.

46. Chiu HF, Chen BK, Lu YY, et al. Hypocholesterolemic efficacy of royal jelly in healthy mild hypercholesterolemic adults. Pharm Biol 2017; 55: 497502.

47. Lambrinoudaki I, Augoulea A, Rizos D, et al. Greek-origin royal jelly improves the lipid profile of postmenopausal women. Gynecol Endocrinol 2016; 32: 835-9.

48. Münstedt K, Henschel M, Hauenschild A, von Georgi R. Royal jelly increases high density lipoprotein levels but in older patients only. J Altern Complem Med 2009; 15: 329 30.

49. Hadi A, Najafgholizadeh A, Aydenlu ES, et al. Royal jelly is an effective and relatively safe alternative approach to blood lipid modulation: A meta-analysis. J Funct Foods 2018; 41: 202-9.

50. Yoneshiro T, Kaede R, Nagaya K, et al. Royal jelly ameliorates diet-induced obesity and glucose intolerance by promoting brown adipose tissue thermogenesis in mice. Obes Res Clin Pract 2016. (doi: 10.1016/j.orcp.2016.12.006).

51. Takaki-Doi S, Hashimoto K, Yamamura M, Kamei C. Antihypertensive activities of royal jelly protein hydrolysate and its fractions in spontaneously hypertensive rats. Acta Med Okayama 2009; 63: 57-64.
52. Fan $\mathrm{P}$, Han B, Feng $M$, et al. Functional and Proteomic Investigations Reveal Major Royal Jelly Protein 1 Associated with Anti-hypertension Activity in Mouse Vascular Smooth Muscle Cells. Sci Rep 2016; 6: 30230.

53. Townsend GF, Morgan JF, Tolnai S, Hazlett B, Morton HJ, Shuel RW. Studies on the in vitro antitumor activity of fatty acids I: 10-hydroxy-2-decenoic acid from royal jelly. Cancer Res 1960; 20: 503-10.

54. Shirzad M, Kordyazdi R, Shahinfard N, Nikokar M. Does Royal jelly affect tumor cells? J Herbmed Pharmacol 2013; 2: 45-8.

55. Izuta H, Chikaraishi Y, Shimazawa M, Mishima S, Hara H. 10-Hydroxy-2-decenoic acid, a major fatty acid from royal jelly, inhibits VEGF-induced angiogenesis in human umbilical vein endothelial cells. Evid Based Complement Alternat Med 2009. (doi: 10.1093/ecam/nem152).

56. Zhang S, Shao Q, Shen Z, Su S. Immunomodulatory response of $4 \mathrm{~T} 1$ murine breast cancer model to camellia royal jelly. Biomed Res 2017; 28: 1223-30.

57. Šver L, Oršolić N, Tadić Z, Njari B, Valpotic I, Bašic I. A royal jelly as a new potential immunomodulator in rats and mice. Comp Immunol Microbiol Infect Dis 1996; 19: 31-8.

58. Kohno K, Okamoto I, Sano O, Arai N, Iwaki K, Ikeda M, Kurimoto $M$. Royal jelly inhibits the production of proinflammatory cytokines by activated macrophages. Biosci Biotechnol Biochem 2004; 68: 138-45.

59. Vucevic D, Melliou E, Vasilijic S, Gasic S, Ivanovski P, Chinou I, Colic M. Fatty acids isolated from royal jelly modulate dendritic cell-mediated immune response in vitro. Int Immunopharmacol 2007; 7: 1211-20.

60. De Waal-Malefyt R, Abrams J, Bennett B, Figdor CG, De Vries JE. Interleukin 10 (IL-10) inhibits cytokine synthesis by human monocytes: an autoregulatory role of IL-10 produced by monocytes. J Exp Med 1991; 174(5): 12091220.

61. Gasic S, Vucevic D, Vasilijic S, Antunovic M, Chinou I, Colic M. Evaluation of the immunomodulatory activities of royal jelly components in vitro. Immunopharmacol Immunotoxicol 2007.

(doi: 10.1080/08923970701690977).

62. Kwon HO, Lee M, Cho YH, Jun W, Lee J. Royal jelly supplementation ameliorated immune impairment via inhibition of oxidative stress in low micronutrientinduced immunodeficient mice. J Food Nutr Res 2017; 5: 74-9. 
63. Zargar HR, Hemmati AA, Ghafourian M, Arzi A, Rezaie A, Javad-Moosavi $S A$. Long-term treatment with royal jelly improves bleomycin-induced pulmonary fibrosis in rats. Can J Physiol Pharmacol 2016; 95: 23-31.

64. Mannoor MK, Shimabukuro I, Tsukamotoa M, Watanabe $\mathrm{H}$, Yamaguchi K, Sato Y. Honeybee royal jelly inhibits autoimmunity in SLE-prone NZB× NZW F1 mice. Lupus 2009; 18(1): 44-52.

65. Zahran AM, Elsayh KI, Saad K, et al. Effects of royal jelly supplementation on regulatory $T$ cells in children with SLE. Food Nutr Res 2016; 60: 32963.

66. Erem C, Deger O, Ovali E, Barlak Y. The effects of royal jelly on autoimmunity in Graves' disease. Endocrine 2006; 30: 175-83.

67. Fratini F, Cilia G, Mancini S, Felicioli A. Royal Jelly: An ancient remedy with remarkable antibacterial properties. Microbiol Res 2016; 192: 130-41.

68. Alreshoodi FM, Sultanbawa Y. Antimicrobial Activity of Royal Jelly. Antiinfect Agents 2015; 13: 50-9.

69. Brudzynski K, Sjaarda C. Honey Glycoproteins Containing Antimicrobial Peptides, Jelleins of the Major Royal Jelly Protein 1, Are Responsible for the Cell Wall Lytic and Bactericidal Activities of Honey. PLoS One 2015. (doi: 10.1371/journal.pone.0120238).

70. Meto A, Meto A, Xhajanka E, Ozcan M, Tragaj E. Microbiological Comparison of Royal Jelly and Chlorhexidine $\quad 0.2 \%$. European Journal of Interdisciplinary Studies 2017; 7: 122-5.
71. Dinkov D, Stratev D, Balkanska R, Sergelidis D, Vashin I. Reduction Effect of Royal Jelly and Rape Honey Alone and in Combination Against Methicillin-Resistant Staphylococcus aureus (MRSA) Strains. J Bacteriol Virol 2016; 46: 36-43.

72. Stratev D, Vashin I, Balkanska R, Dinkov D. Antibacterial activity of Royal jelly and rape honey against Aeromonas hydrophila (ATCC 7965). J Food Health Sci 2015; 1: 67-74.

73. Mierzejewski M. The antimicrobial effects of royal jelly, propolis and honey against bacteria of clinical significance in comparison to three antibiotics. Available at: https://www.newhaven.edu/_resources/documents/ academics/surf/past-projects/2013/monica-mierzejews ki-paper.pdf (Accessed on: 1 Feb 2018)

74. Susilowati H, Murakami K, Yumoto H, et al. Royal Jelly Inhibits Pseudomonas aeruginosa Adherence and Reduces Excessive Inflammatory Responses in Human Epithelial Cells. Biomed Res Int 2017. (doi: 10.1155/2017/3191752).

75. Moghim H, Taghipoor S, Shahinfard N, Kheiri S, Khabbazi $\mathrm{H}$. Comparative study on the antifungal activity of hydroalcoholic extract of Iranian Propolis and Royal jelly against Rhizopus oryzae. J Herbmed Pharmacol 2015; 4: 89-92.

76. Siavash M, Shokri S, Haghighi S, Shahtalebi MA, Farajzadehgan $Z$. The efficacy of topical royal jelly on healing of diabetic foot ulcers: a double-blind placebocontrolled clinical trial. Int Wound J 2015; 12: 137-42.

77. Thien FCK, Leung R, Baldo BA, Weinbr J, Plomley R, Czarny $D$. Asthma and anaphylaxis induced by royal jelly. Clin Exp Allergy 1996; 26: 216-22. 